\title{
GLOBALIZATION AND ITS IMPACT ON HIGHER EDUCATION: A CASE STUDY OF NIGERIA AND PAKISTAN
}

\author{
Lawal Mohammad Anka \\ Director Planning Monitoring and Evaluation Zamfara, \\ Agricultural Development Project, \\ Nigeria \\ Email: $\underline{\text { awal550@gmail.com }}$
}

\begin{abstract}
The main purpose of this paper was to find out how globalization has influenced learning process improvement in Nigeria and Pakistan. Identify the impact of Globalization in the educational reform revolution, service, delivery of scholars/ research in Higher education. Qualitative research methodology was used as it focuses on the need to document a set of policies, reforms and practices that will focus on changes as a result of Globalization with particular reference to Nigeria and Pakistan. It also includes identifying the role education can play in equipping individuals to participate more fully in their countries development and positioning the two countries to participate in global economy. The major conclusions drawn from this paper were Globalization has opened up a wider horizon in teaching. research and academic linkages for the two countries. Learning opportunities have improved remarkably since the advent of information technology and Globalization process. Indigenous knowledge has been promoted and enrolment has tripled. On the basis of the above findings the following recommendations were made:(1) Investment in areas of research and ICT that will enhance teaching / learning process is needed. Innovation and leadership two qualities in greatest need within the two countries education sector. Stronger partnership needs to be developed between local universities and foreign universities.
\end{abstract}

\section{KEYWORDS}

Globalization. Higher Education, Educational Reforms and Impact

\section{INTRODUCTION}

Globalization can be defined as a process of integration of local characteristics 
into global flows which are mostly done by means of new communication and information technology. It is historically seen as a process integrating local economies into world economy. Where the local and global interact, it seems to refer to a space and information and communication are the means of interaction technologies (Tapper, 2000). It refers to the increasing integration of economies around the world particularly through trade and financial flows, the term refers to the movement of people (labour) and knowledge (Technology) across international borders (Azad, 2016) describes globalization as the fast development in communication technology.

Globalization has a lot of meanings, to many institutions now include the term global in their mission statement most aspire to prepare globally competent graduates. For some, the term globalization and internationalization are interchangeable. Yet globalization is a term that is not well defined with different meanings and different groups and globalization is a term that is value Laden and controversial. Globalization has a close relation with education because education has an important place in shaping our society. (Abdulhadi \& Ahmad,2015) Globalization has to be connected with education and the global activities have a deep impact on it. Globalization of world economies is leading to increase emphasis on internationalization of the subject included on a course of study. It creates opportunities for new partnership in research and teaching with agencies and institutions across the world (Twiggs and Oblinger, 1996).

In the field of education a lot changes are expected, duties of schools is to ameliorate the individual's appropriateness with the concept of globalization that changes traditional structure of education, which is one of the main rapid changes today in universities and other institutions that are redoubling their efforts to respond to social change.(Ndaaba, 2017)

Gordon outlines the importance of higher education in the learning society by attributing the report of the National Committee of inquiry into higher education as follows: Higher education is principal to the social, economic and cultural health of a nation. It contributes to intellectual development of students and by preparing them for work but also by adding to the world store of knowledge and understanding.

In the quotation of Gordon said that "Higher education is very important in different domains and it contributes as in the promotion of students' knowledge 
and helping them to integrate in job market. Universities and other institutions of higher learning will be open to anyone who has acquired motivation to learn. As higher education is an investment in human progress and prosperity during the past social and economic change. It is important that universities should consider their contributions to society from abroad long-term perspective.

Higher Education is a major foundation in implementing the complex process of globalization. Advanced information technology and revolution in higher education have already been expanding beyond what was in the past decades. Higher education has moved from a peripheral to a central position in the responses of government to globalization. It is a key factor in both Nigeria and Pakistan. It is against this background that this paper sought and know the educational reforms and impact of Globalization and its challenging role in the higher education in both two countries.

\section{REVIEW OF LITERATURE}

According to Kilminister the Word Globalization first appeared in webster's English dictionary in 1961. Going back to history, the word Globalization was first coined by Ronald Robertson. This scholar believes that Globalization is a pre-modern phenomenon that has already started in the fifteenth century with European Colonial policy of expansionism to subjugate most parts of Asia and Africa. Though, colonization the western powers then tried to expand their powers and influence on under-developed countries in the world.

Misra (2012) considers the global transformations requires that people develop new skills, new experiences, new knowledge and schools have an important role to play in this regard. The role of teachers and the way they should teach in this new high-tech global economy, people are learning in new ways for new purposes and schools adapt themselves for this new reality and rearrange their skills achievements and previous experiences to adopt themselves to new opportunities.

Ashraf and Peter (2010) stated that there is sufficient evidence to show that due to Globalization and universalization in education policies in Pakistan, the enrolment rate and female literacy at primary level has increased. Similarly, the dropout rate has increased in all other stages. Privatization of education promoted education and contributed in GDP of the country but remained a source of inequality and widened socio-economic divide. 
Chinnammal (2005) opined that, the effects of Globalization on education brings rapid developments in technology and communications are foreseeing changes within the learning systems across the world of ideas, values and knowledge changing the role of teachers and students and producing a shift in society from industrialization towards an information-based society.

Sajid and Malik (2009) highlights the effects of Globalization on educational reforms which are competitiveness driven, finance driven and equity driven. The paper argues that Globalization has seriously challenged the national reforms policies which are now becoming more and more globally driven. Rather than out rightly rejecting all global policies engaging critically with them is the stance of the authors.

Abdulhadi and Ahmad (2015) observe that Globalization represents theoretically as well as practically a challenge for education. Accordingly, Globalization has to be adapted by educational concepts. The observable phenomenon that appear as part of Globalization push us to the following questions. How can education be affected by Globalization? And is there any space for educational concepts like equal opportunities, democracy and common sense? Is there any space for the nation, state and national identity?

Azad (2014) stated that, Globalization is impacting on institutional framework in both developing and industrial countries. It is changing the way in which Governments perceived their roles in society. It has also far reaching implication for socio economic development and educational systems of countries all over the world.

Anka and Khaskelli (2011) concluded that, many universities give emphasis on recognition of scholarly teaching in the form of rewards and in promotion decisions. Lack of coordinated and collaborative university wise approach affects quality of teaching programmes in Nigeria universities. The need for addressing the issue of quality in higher education in Nigeria is strongly felt when students are seen struggling in the global work force market, resulting in creating obstacle to national development.

\section{Conceptual framework}

The conceptual framework for this research focus on in-depth exploration of the impact of Globalization on higher education in Nigeria and Pakistan 
explored through detailed secondary data collection from various sources. It includes articulation of research questions, a thorough description of the context, the identification of issues related to Globalization and Higher education and an analysis of information and data gathered.

\section{OBJECTIVES}

1. Examine teaching, learning and Globalization.

2. Assessment of productivity Quality research, equity and excellence.

3. Find out how Globalization has influenced learning process improvement in Nigeria and Pakistan Higher Education.

4. Identify the impact of Globalization in the educational reform revolution, service delivery of scholars / research in higher education.

\section{RESEARCH QUESTIONS}

1. How do Education stakeholders understand globalization and its impact on education Globally?

2. Have Education Reforms better positioned Nigeria and Pakistan to respond to opportunities and challenges of Globalization?

3. To what extent does Globalization influence the quality of research / scholarly output in Nigeria and Pakistan?

4. To what extent does Globalization helps in improving learning process in Nigeria and Pakistan Higher Education?

\section{RESEARCH METHODOLOGY}

Qualitative research methodology addresses the purpose of the study as it encourages detailed description and fits with the need to document a set of policies reforms and practices that will focus on changes in Higher education with particular reference to Nigeria and Pakistan. A qualitative approach also supports interpretative objectives.

These objectives include determining how education stakeholders in Nigeria and Pakistan understand Globalization and how they put their understanding into education strategy and practice. They include discerning the meaning of relevance for students whose lives will be lived on fault line between the local and global. They also include identifying the role education can play in equipping individuals to participate more fully in their countries development and in positioning the country for participation in the global economy. 


\section{FINDINGS}

The major findings drawn from this paper were:

Globalization has really promoted collaboration amongst Nigeria scholars' researchers and policy makers.

Indigenous knowledge has been promoted and a shift in traditional method of teaching and learning process has been greatly noticed.

Globalization has open up a wider horizon for co-researchers not only in Nigeria \& Pakistan but in other developing countries.

Learning opportunities have improved remarkably in Nigeria since the advent of information technology and Globalization process.

Globalization has hastened the pace of migration and created a better placement for Pakistani graduates worldwide.

The quality of $\mathrm{PhD}$ degrees being awarded in Pakistan is highly respected because of the strict quality assurance implemented.

One impact of Globalization on higher education in Pakistan was the urgency to develop a skilled work force at all levels to meet the demands of increasing business environment.

Due to the Globalization of higher education, university Enrolment has tripped throughout Pakistan.

\section{DISCUSSIONS}

\section{Teaching and Education Systems in the Global Context:}

The challenge for future public education is to give priority to teaching ethics and a sense of global responsibility that go beyond the bounds of knowledge economy. Second Globalization promotes competition although strategic alliances between competing parties are becoming a condition of success. As a consequence, similar doctrines have emerged in education.

Standards, testing and alternative forms of financing have come to challenge conventional public education in many countries. In the name of accountability and transparency, school teachers and students are measured, tested and asked to perform under the Global Managing, Transitions, Teaching and Globalization serving eyes of external inspectors.

Even Ministers of Education today compete to determine which students can perform the best in international student assessment programmes. According to Carnoy, (1999) the approach which governments take in reforming their 
education sector and its responses to Globalization depends on three key factors:

(a) The Government objective financial situation.

(b) Its interpretation of that situation.

(c) Its political ideological position regarding public education.

\section{Impact of Globalization on Higher Education Around the Globe}

The effects of Globalization on education bring faster developments in Technology and Communications are foreseeing changes within school systems across the world as ideas, values and knowledge changing the roles of students and teachers and producing a shift in society from industrialization towards an information - based society.

The nature of delivering education to students is being changed by introduction of Technology into the classroom, is gradually giving way to a new form of electronic literacy as more programmes and education materials are made available in electronic form, teachers are preparing materials in electronic form and students are generating papers, assignments and projects in electronic form. Video projection screens, books with storage device and CD Roms as well as the rise of digital libraries are now replacing blackboards. Even exams and grades are gradually becoming available by electronic means and notebooks are starting to give way to laptops. Also, students can be examined through computer Managed Learning System and do tutorial exercise on a computer rather than classroom. Such a development in education portray that there has been a shift from industrialization to information-based societies.

While, education institutions in Western societies are adopting technology less developed countries are once again left behind, very weak and fragile to implement development programs for education. Severe limitations in delivering basic services are a problem. A lack of infrastructure and funding makes it difficult to implement any technological and communication development. (Menon, 2006)

\section{Enhancement of Productivity in Education}

The basic objective of Globalization is to enhance productivity and to make educational system an instrument of preparing students who can compete in world markets as productive members of society. This would necessitate making skill training an integral part of the curriculum besides making 
attitudinal changes so that the students do not consider it difficult to work with hands. (Tarar, 2006) Unfortunately, our experience of introducing an element of skill training has not been successful adequately. Education is still considered as an academic discipline in which the instructions of vocational training is considered unacceptable. There is also lack of parity of status between students and teachers of vocational and general stream leading to the former hesitating to join vocational courses.

\section{Higher education reforms in Nigeria}

The government of Nigeria recently initiated higher education policy reforms intended to bring its university system in-line with international best practices. The reforms promoted, increased institutional autonomy, greater system differentiation, strengthen government and mechanism for quality assurance. They seek to create a more flexible and responsive system of university teaching and research that over the time will contribute tremendously to national innovation capacities productivity gains and economic growth. (Abdulkarim \& Fasasi, 2016)

\section{Higher education policies since 1998}

The year 1999 brought a democratically elected government to Nigeria. For the first 15 years there was a political will to tackle the nation's long festering higher education difficulties. Indeed, the present government has instituted more policy and institutional reforms in higher education than the combined governments of the previous two decades.

Among its more notable action are institutional audits of all universities, renovation of Vice Chancellors former privileges of personally selecting $10 \%$ of each year student intake, reconstitution of all universities governing councils with broader representation and $180 \%$ increase in funding of the university system that raised per student allocations from equivalent of USD 970 per year.

Crowning these efforts was a new Government policy on Autonomy for universities announced in July 21, 2001. In May, 2002, a resulting set of Legislative proposals designed to reform existing higher education Laws and establish a permanent legal basis for these changes was approved by the Government. 


\section{Assessment of quality}

In Nigeria, three pieces of evidence suggested the need for greater attention to innovation in both curricular and pedagogy. First student success seems limited. Dropout rates appear to be high second public and private employees of university graduates as well as Government itself considered the quality of university graduates to be inadequate. Third, university curriculum lacks quality. The National Universities Commission completed nationwide accreditation exercise from time to time since 2000 that revealed widespread shortcoming in curricular (Saint, et al 2003).

The factors responsible for poor quality of university programs and graduates appear to be both internal and external to the universities. The present government has aggressively addressed these identified problems through a series of policy changes.

\section{Newly Higher Education Reforms 2006 to Date}

New higher education reforms have recently been initiated in Nigeria. They respond to long festering problems of Access, quality, financing, governance and management within the nation's Federal University System and seek to bring this system more in line with global best practices.

\section{Access}

Appropriate steps are being taken to increase access to higher education through development of a private university sector and establishment of nationwide tertiary distance education programs.

\section{Teaching / Learning}

Much of university teaching in Nigeria is based on traditional pedagogy and conventional curricular and does not meet the Government's own standards in these areas. To increase the relevance and effectiveness of teaching and research classroom dynamics may need to focus more on student learning performance.

\section{Financing}

Continued expansion of the higher education system has now exceeded government capacity to serve as the principal financier of this growth. Under this conditions, local income generation takes on added importance and also 
serve to reinforce policies promoting decentralization and institutional autonomy.

\section{Government / Management}

Increasingly, large and complex institutions of higher learning demand the application of professional management techniques, strategic vision, more proactive corporate management styles that address problems through innovation and governance structures that facilitate institutional responsiveness to the wide range of university stakeholders. The government policy reform package has been adequately designed but possibly not well explained to higher education stakeholders. The Academic Staff Union of Nigerian Universities (ASUU) and National Association of Nigerian Students oppose this policy. Statements from these groups suggest that their resistance is based on substance of the autonomy legislation and on fears of a government hidden agenda to commercialize and privatize higher education.

\section{Pakistan Higher Education Reforms}

The Higher Education has historically been quite a decentralize structure in Pakistan whereby each public sector university work quite independently with minimum interference. In 2001 the Ministry of Education launched a Task force on improvement of Higher Education in Pakistan. The Task force after a yearlong deliberation submitted its report to the Ministry of Education which resulted in huge restructuring of Higher Education in Pakistan.

The Taskforce see Higher Education as a key pillar for economic growth of the country and an investment in developing the human capital. The key recommendations of the Task Force were establishment of Higher Education Commission with more funding and power at its disposal such as restructuring of universities management and governance structures linkages with industry and strong emphasis on Science and Technology, building research culture and revision of curricular. It is interesting to note that, the recommendations of Higher Education Task Force in Pakistan appear the following directly from recommendations of International Task Force on Higher Education in developing countries Task Force on Higher Education and Society (2000).

The privatization of education in Pakistan seems driven by Finance driven reforms. All of the policy documents of Pakistan education recommend 
privatization because the Government simply do not have the resources both human and capital (Ashraf \& Peter, 2015).

The decentralization reforms are patterned on both competitiveness - driven and to some extent equity driven reforms. The decentralization on the one hand supposed to make the delivery of education much better and hence improve the quality of the product student. On the other hands it is also supposed to make education system more responsive to local needs (Anka \& Khashkelli, 2011) The Higher Education reforms and the push for generation of numbers are predominantly competitiveness driven reform. Higher Education reforms can be justified on financial grounds as the tertiary education prepares human capital which is very much sought after by global capital. In fact, Education stakeholders in Pakistan recognize that the growth of Higher education is needed to ensure sufficient human capital growth for the country. (Darwish, 2016).

Looking at the situation in Pakistan, we argue that education reforms in Pakistan are tainted by the global education policy field. The privatization, decentralization, Higher Education reforms appear to be imbibed within the logic of globalization. In fact, the Higher education reforms, have a very apparent global look (Ali, 2006) most other policies also appear to be influenced by global developments.

The decentralization reforms seem like a home-grown idea that respond to local needs; however, this idea has already been declared a part of the so called, Washington Consensus. Similarly, the privatization of education is also part of the global policy field.

\section{Impact of Globalization on Higher Education in Nigeria}

Globalization has really promoted collaboration among Nigerian scholars, researchers and policy makers. Indigenous knowledge has been promoted and shift in traditional method of teaching and learning process has been greatly noticed. The use of modern technology, i.e. Internet with visibility has added more value to the quality of research carried out in the education sector analysis.

This brings about a posture charge in the achievement of the set educational goals. Globalization has open up a wider horizon for co-researchers not only in Nigeria but also in other developing countries. Internationalization of 
resources has permitted researchers and scholars with different culture and locations to show case what is obtained in their environments. (Kolawole, Aderonke, O.O and Olusunkanmi, 2015).

Learning opportunities have improved remarkably in Nigeria since the advent of information technology and Globalization process. The ubiquitous learning resources on the web have sparred scholars to take collaborative strides in the pursuit of knowledge. More importantly, is its influence in distance learning in which a learner can register as a student at his/her location and receive instruction on line (Abdullahi \& Ahmad, 2015).

Globalization has had great influence on the promotion of indigenous knowledge, thus Nigerian higher education has greatly improved through Globalization and this has shown in the trend of higher education through enrolment rate, graduation rate and level of manpower development. This indeed have positive impact on national development and economic planning thus moving the education sector to a higher degree of scholastic improvement through improved information dissemination service delivery. policy making. curriculum improvement and capacity building of both scholars and researchers in education (Kolawole, Aderonke, O.O and Olusunkanmi, 2015).

\section{Impact of Globalization on Higher Education in Pakistan}

The new educational reform program implemented by Higher Education Commission of Pakistan had direct impact on Higher Education in many ways. This include:

i. Establishment of digital Library which is regarded as one of the best digital libraries anywhere in the world. Every student in every public sector university has access to more than 45,000 textbooks and research monographs from 220 International Research Journals completely free of charge.

ii. University enrolment has tripled; it was only 135,000 in 1947 . But from 2004 to 2008 it increased to 400,000 from 2008 to 2018 it doubled to 800,000. iii. There were only 59 universities and Degree awarding institutions in 2001 in Pakistan. These grew to 127 in 2008 and to almost 250 in 2018.

iv. More than 5,000 $\mathrm{PhD}$ scholarships were awarded for study in technologically advanced countries one of the largest programme in developing countries with about RS10million spent on one student. Some 4,000 indigenous scholarships were also awarded.

v. The world Largest Fulbright Scholarship Programme US Dollars 150 million 
was launched with Joint Funding form USAID to send 640 students to top universities in USA.

vi. The quality of PhD degrees being awarded in Pakistan is being strengthened by making it mandatory that they should be evaluated by at least two foreign experts in developed countries.

vii. Quality assurance units were set up in all universities so that they could have their own peer review of the processes and regular external peer reviews were also initiated.

viii. A strict monitoring system of all university projects was introduced to ensure that the funds were properly spent.

ix. One impact of Globalization on higher education is the urgency to develop a skilled work force at all levels to meet the demands of increasing business environment.

$\mathrm{x}$. Globalization has hastened the pace of migration and created better placement for Pakistan graduates and other professionals worldwide.

The objectives of the study were to find out how Globalization has influenced learning process improvement in Nigeria and Pakistan Higher Education. The study also identifies the impact of Globalization in the educational reform revolution, service delivery of scholars/researcher in higher education. Qualitative research methodology focuses on the need to document a set of policies reforms and practices that will focus on changes in higher education with particular reference to Nigeria and Pakistan. It also includes identifying the role education can play in equipping individuals to participate more fully in their countries development and positioning the two countries for participation in the Global economy.

\section{RECOMMENDATIONS}

\section{Recommendations for Nigeria}

Education stakeholders should commit to assuring quality of global provision of higher education through awareness in different fields.

Investment in areas of research and ICT that will enhance teaching / learning process on higher education is needed.

Before Globalization can take place facilities (human and physical funds) should be made available for execution.

Proper funding in higher Education is needed to attain the status of becoming a global brand.

There is need for awareness by keeping the public informed on the latest happening in globalization trends in higher education. 
It is important that assessment and evaluation of education reforms be conducted at all stages of implementation in order to ensure that reform agenda is in line with expectation of the initiators.

\section{Recommendations for Pakistan}

Change the role of Government into facilitation and supervision through adequate regulatory measures.

De-License higher education, confer Institutional autonomy and decentralize syllabus design.

Innovation and leadership two qualities in greatest need within Pakistan higher education today.

Stronger partnership needs to be developed between Pakistan Universities and foreign Universities.

Government is required to facilitate privatization and deregulation in education particularly as quality of education in some institutions still remain poor.

For Pakistan to broaden and expand its pace in the global market place of higher education will required bold and innovative leadership of Vice Chancellors, policy makers at all levels.

A more systematic focus on institutional partnership could also become part of Pakistan's approach to bilateral scholarly exchange programme.

\section{General Recommendations}

Increase University revenue through internal and external sources especially linkage with the private sector so as to ensure optimal funding of teaching and research.

Identify areas of strength in each university to develop centers of Excellence. Revise procedures for staff recruitment, promotion and professional updating in line with changing trend of Globalization to ensure buildup of a competent faculty.

Rationalize the number of credit hours and courses offered at both undergraduate and post-graduate levels.

Restore linkages between university teaching, research and community services to have positive impact on higher education. 


\section{REFERENCES}

Alam, M. (2012). Assessment of Oral Skills Development among the Students of Master in Education in the Public Sector. Sarghoda: University of Sarghoda.

Alam, Q., \& Uddin, A. B. (2013). Improving English Oral Communication Skills of Pakistani Public School's Students . International Journal of English Language Teaching, 1(2), 17-36.

Alonso, R. A. (2013). Teaching Speaking: An Exploratory Study in Two Academic Contexts. Porta Linguarum, 22, 145-160.

Ashton, P. T. (1990). Editorial. Journal of Teacher Education, 42(1), 2.

Begum, A. D. (2002). Measuring socio-economic. In A. D. Begum, Measuring socioeconomic gender inequality in: Towards an alternative to the UNDP genderrelated development index. (p. 251: 30.). The Hague: Instt. of Social Studies.

Brookhart, B. A., \& Freeman, D. J. (1992). Characteristics of entering teacher candidates. Review of Educational Research, 62(1), 37-60.

Brown, G., \& Yule, G. (1999). Teaching the Spoken Language. Cambridge : Cambridge University Press.

Burns, A., \& Joyce, H. (1997). Focus on Speaking. Sydney: National center for English Language Teaching and Research.

Canale, M., \& Swain, M. (1980). Theoretical Bases of Communicative Approaches to Second Language Teaching and Testing. Applied Linguistics, 1- 47.

Chomsky, N. (1965). Aspects of the Theory of Syntax. MIT Press.

Clark, C. M. (1988). Asking the right questions about teacher preparation: Contributions of research on teaching thinking. Educational Researcher, $17(2), 5-12$.

Clark, C., \& Peterson, P. (1986). Teachers' thought processes. In M. Wiltrock, Handbook of Research on Teaching (3rd ed., pp. 255-296.). New York: Macmillan.

Clark, S. C. ( (2000).). Work/family border theory: A new theory of work/family balance. Human Relations, 53, , 747-770.

Creswell, J. W. (2011). Educational Research planning, conducting, and evaluating quantitative and qualitative research. Pearson.

Dawes, L. (2005). Speaking, Listening and Thinking with Computers. In E. Grugeon, L. Dawes, C. Smith, \& L. Hubbard, Teaching Speaking \& Listening in the Primary School. David Fulton.

De Souza, C. (1963). "The call of working Mother. Social Action, ",, 640-646.

Démuth, A. (2013). Perception Theories. Trnava.: Faculty of Philosophy.

Desai, V. (1967). Social Aspects of Savings, . .Bombay: : Popular Prctka;han.

Diener, E. S. ((1999). Subjective well-being: Three decades of progress. . Psychological Bulletin, , 125, 276-302. 
Esmail, A., Ahmed, M., \& Noreen, S. (2015). Why Do Pakistani Students are Reluctant to Speak English. Academic Research International, 6(3), 372-383.

Farooq, M. U. (2015). Creating a Communicative Language Teaching Environment for Improving Students' Communicative Competence at EFL/EAP University Level. International Education Studies, 8(4), 179-191.

Francis, J. J. (2004). Constructing Questionnaires Based On The Theory Of Planned Behaviour A Manual For Health Services Researchers. . University Of Newcastle,C.

Frone, M. R. ((1992) ). 'Antecedents and outcomes of work-family conflict: Testing a model of work-family interface'.. Journal of Applied Psychology, 77 (1), : 6578.

Greenhaus, J. H. ( (1985)). 'Sources of conflict between work and family roles'. Academy of Management Review, 10 (1): , 76-88.

Grugeon, E., Hubbard, L., Smith, C., \& Dawes, L. (2005). Teaching Speaking and Listening in the Primary School. Routledge.

Guest, D. ). ((2002). 'Perspectives on the study of work-life balance',. Social ScienceInformation, 41(2), 255-79.

Halliday. (1975). Learning how to mean . Oxford University press.

Harb, J., Bakar, N. A., \& Krish, P. (2013). Instructors' and Students' Perceptions Towards using Technology in Teaching and Learning Listening and Speaking at Jordanian Universities. Interdisciplinary Journal of Contemporary Research in Business, 4(9), 1027-1041.

Harmer, J. (2001). The Practice of English Language Teaching. Edinburgh: Pearson Education limited.

Hochschild, A. ,. (1997). The Time Bind: When Work Becomes Home and Home Becomes Work. New York:: Metropolitan Books.

Hom, P.W., and Kinicki, A.J.,. (2001). "Toward a greater understanding of how dissatisfaction drives, employee turnover",. The Academy of Management Journal, Volume No.44(5),,, pp.975- 987.

Hymes, D. (1972). On communicative competence. In J. B. Pride, \& J. Holmes, Sociolinguistics: selected readings (pp. 269-293). Harmondsworth: Penguin.

Jabeen, A. (2015). The Role of Error Analysis in Teaching and Learning of Second and Foreign Language. Education and Linguistics Research, 1(2), 52-61.

Jabeen, I. (2013). English Language Teaching Implementing Collaborative Language Learning ApproachIn Federal Colleges of Pakistan. (Pakistan Research Repository) Retrieved from Pakistan Research Repository.

Jenkins, J. (2003). World Englishes. Routledge.

Kachru, B. B. (1985). Standards, codification, and sociolinguistic realism: The English language in the outer circle. In R. Quirk, \& ELG.Widdowson (Eds.), English in the World: Teaching and Learning the language and the literature (pp. 1130). Cambridge : Cambridge University Press. 
Kagan, D. (1992). Implications of research on teacher beliefs. Educational Psychologist, 27(1), 65-90.

Kayi, H. (2006, November). Teaching Speaking: Activities to Promote Speaking in a Second Language. The Internet TESL Journal. Retrieved from The Internet TESL Journal

Kirchmeyer, C. .. ((2000)). In C. \&. (Eds.), Work-life initiatives: (pp. pp. 79-93).). West Sussex,UK: Wiley: ,Trends in organizational behavior.

Kofodimos, J. R. ((1993). Balancing act. . San Francisco: : Jossey-Bass.

Lightbown, P. M., \& Spada, N. (2006). How languages are learned (3rd ed.). Oxford University Press.

Mahmood, A., \& Ghani, M. (2012). Communicative Skills of Student Teachers in Pakistan. International Journal of Research in Linguistics and Social \& Applied Sciences, 1, 74-89.

Malik, Z. A. (2008). Discovering identities of teachers of English in Pakistan. Discovering identities of teachers of English in Pakistan. Aga Khan University, Karachi, Pakistan.

Manan, S. A., David, M. K., \& Dumanig, F. P. (2016). Language management: a snapshot of governmentality within the private schools in Quetta, Pakistan. Language policy, 15(1), 3-26.

Manan, S. A., Dumanig, F. P., \& David, M. K. (2015). The English-medium fever in Pakistan: analyzing policy,perceptions and practices through additive bi/multilingual education lens. International Journal of Bilingual Education and Bilingualism, 1-17.

Mani, v. (2013). Work Life Balance and Women Professionals. Global Journal of Managemen tand Business Research Interdisciplinary ; $13(5$.

Mark Tausig and RudyFenwic. (2001). "Unbinding Time: Alternate Work Schedules Work-Life Balance". , Journal of Family and Economic Issues, Volume No.22(2), Human Sciences Press, ,, pp.101-119.

McLeod, S. (2007). Visual Perception Theory. Retrieved from SImply Psychology: www.simplypsychology.org/perception-theories.html

Nawab, A. (2012). Is it the way to teach language the way we teach language? English language teaching in rural Pakistan. Academic Research International, 2(2), 696-705.

Neetu, 1. ((2009)). Social Justice \& Empowerment.

Netemeyer, R. B. ( (1996) ). 'Ddevelopment and validation of work - family conflict and family - work conflict scales'. . Journal of Applied Psychology, 81(4)., : 400-410.

Nunan, D. (2003). Practical English Language Teaching. McGraw-Hill Education.

Nye, F.I.Hoffman,L.W. (1963). "the employed Women in America". Chigago: Rand Mcmally and comoany. 
Osborn, M. M., Pearson, J. C., \& Morreale, S. P. (2000). Why Communication is Important: A Rationale for the Centrality of the Study of Communication. Journal of the Association for Communication Administration, 29(1), 1-25.

Patil, Z. N. (2008). Rethinking the Objectives of Teaching English in Asia. Asian EFL Journal, 10(4), 227-240.

Paulston, C. B. (1992). Linguistic and Communicative Competence: Topics in ESL. Multilingual Matters.

Perez-Gore, I., McCormick, R., Burton, S., \& Siddique, M. A. (2011). Perceptions of English Language Learning and Teaching Among Primary and Secondary School Teachers and Students Participating in English in Action. Dhaka, Bangladesh: English in Action (EIA).

Perlow.L.A. (1995). Putting the work back into work/family. Group and Organization Management, ,, 20(2): 227-39.

Pietromonaco, Paula.R. (1986). " Psychological consequences of Multilpe social Roles.". psychology of Women Quarterly, vol 10.

Polit, D. F., \&. Hungler, B. P. ((1999).). Nursing Research: Principles and Method. . Lippincott( 6 ed.).

Pramanik, R. (2011). Information and Communication Technology (ICT) among School-going Children.

Rahman, T. (2006). Language policy, multilingualism and language vitality in Pakistan. Trends in Liguistics Studies and Monographs, 175, 73-106.

Richards, J. C., \& Rodgers, T. S. (1986). Approaches and Methods in Language Teaching. Cambridge University Press.

Richards, J. C., \& Schmidt, R. (2010). Longman Dictionary of Language Teaching and Applied Linguistics. pearson.

Rickheit, G., Strohner, H., \& Vorwerg, C. (2008). The concept of communicative competence. In G. Rickheit, \& H. Strohner, Handbook of Communication Competence :Volume 1 of Handbooks of applied linguistics (pp. 15-62). Walter de Gruyter.

Sarfraz, S., Mansoor, Z., \& Tariq, R. (2015). Teachers' and students' perceptions of the communicative language teaching methodology in the CALL environment: A case study. Procedia - Social and Behavioral Sciences, 199, 730-736.

Savignon, S. J., \& Wang, C. (2003). Communicative language teaching in EFL contexts:Learner attitudes and perceptions. IRAL, 223-249.

Seth, M. .. (1995). Women's Development: Indian Initiatives. KURUKSHETRA-NEW DELHI-, , 43, 33-35.

Shamim, F. (2008). Trends, issues and challenges in English language education in Pakistan. Asia Pacific Journal of Education, 235-249.

Singh, K. (1972). " career and family .women's two roles.". Indian journal of social work ,Bombay. 
Sinha, P. (1976). "Role conflict among Working Women,". New Delhi: Janaki Prakashan.

Smith, C. (2005). Developing Children's Oral Skills at Key Stage 2. In E. Grugeon, L. Dawes, C. Smith, \& L. Hubbard, Teaching Speaking \& Listening in the Primary School. David Fulton Publishers Ltd.

Spitzberg, B. H., \& Cupach, W. R. (1984). Interpersonal Communication Competence. SAGE Publications.

Tariq, A. R., Bilal, H. A., Sandhu, M. A., Iqbal, A., \& Hayat, U. (2013). Difficulties in Learning ENglish as a Second Language in Rural Areas of Pakistan. Academic Research International, 4(6).

Warsi, J. (2004). Conditions under which English is taught in Pakistan : an applied linguistic perspective. SARID Journal, 1(1), 1-9.

Wegerif, R., Mercer, N., \& Dawes, L. (1999, Febuary). Children's Talk and the Development of Reasoning in the Classroom. British Educational Research Journal.

Zeeshan, M. (2016). Pakistani Government Secondary Schools Students' Attitudes towards Communicative Language Teaching and Grammar Translation in Quetta, Balochistan. English Language Teaching, 9(3), 258-270. 